\title{
Grammatisk talesprogsanalyse som tilgang til at studere forståelser af depression
}

\author{
Gengivet sprogbrug som eksempel
}

\section{HANNE SFDERUP PEDERSEN}

\begin{abstract}
I såvel Danmark som $\mathrm{i}$ andre lande er der et ønske om øget samarbejde, 'shared care', mellem almen praksis og psykiatrien i behandlingen af patienter med depression. Gennem interview med henholdsvis praktiserende læger og psykiatere demonstreres, at de to faggrupper har divergerende tilgange til depression: De praktiserende læger udviser en konstruktivistisk, bottom-upforståelse af depression som en foranderlig størrelse, der kan forhandles og modificeres, mens psykiaterne udviser en essentialistisk, top-down-forståelse af depression som en statisk størrelse. Denne forskel kommer til udtryk i faggruppernes gengivelser af deres habituelle sprogbrug om depression. Således bruger lægerne oftere kausative konstruktioner, modalitet samt pronominer med tydelige referenter, mens psykiaterne bruger kopulakonstruktioner, generiske referenter og sjældnere modalitet. Disse forskellige forståelser kan have konsekvenser for ønsket om sambehandling af patienter med depression. Mens hovedparten af sundhedskommunikationsstudier anskues fra et interaktionelt perspektiv, er denne undersøgelse et bidrag til sundhedskommunikation $i$ en repræsentationskontekst, dvs. hvordan læger taler om deres profession og deres patienter frem for $i$ deres profession med deres patienter. Inspirationen til denne analysemetode hentes fra en - $\mathrm{i}$ udgangspunktet litterær - teori om gengivelse af tale og tanke. For at gøre fænomenet anvendeligt til undersøgelse af forstålser af depression indplaceres det i en grammatisk talesprogsramme, og de metodiske implikationer heraf diskuteres.
\end{abstract}

EMNEORD: sundhedskommunikation, depression, talegengivelse, grammatisk talesprogsanalyse, interview 


\section{INTRODUKTION}

I såvel Danmark som $\mathrm{i}$ andre lande er der et ønske om at etablere mere samordnet behandling mellem almen praksis og psykiatrien i behandlingen af patienter med en række affektive lidelser, herunder depression (fx Gask 2005, Davidsen og Fosgerau 2014). Imidlertid er berøringsfladen mellem de to sektorer i dag stadig ganske lille. Et tværfagligt forskningsprojekt ved Københavns Universitet har til formål at undersøge forståelsen af depression i de to sektorer med henblik på at undersøge muligheder og hindringer for øget samarbejde (fx Davidsen og Fosgerau 2014, Fosgerau og Davidsen 2014). På baggrund af interview med de to faggrupper sætter denne artikel fokus på, hvordan praktiserende læger og psykiatere gengiver termer og begreber om depression.

\section{Teoretiske forudsatninger}

McIntyre et al. (2004), der undersøger, hvordan tale, tanke og skrift gengives i engelsk talesprog, anvender det, de kalder Report of Language Use til at beskrive gengivelse af habituel sprogbrug, som i deres eksempel herunder:

(1) What they called the tacklers were over the weavers (McIntyre et al. 2004: 63)

Med inspiration fra McIntyre et al. har jeg fundet det nyttigt at undersøge, hvordan de to lægegrupper anvender dette fænomen i gengivelser af sprogbrug om depression:

(2) INF: jeg tror depression er mange ting de der gamle

\{endogene\} \# som det hed $i$ gamle dage dem ser man

jo ikke så mange af \# vel

INT: \# nej

INF: synes jeg ikke(PL8) ${ }^{1}$

1 Interviewene er udskrevet efter CLAN-konventionerne. Ved eksemplificering af længere, interaktionelle sekvenser er interviewerens bidrag markeret som INT, informantens bidrag som INF. I kortere eksempler tilhører talen informanten, medmindre andet er anført. 
Jeg har på dansk valgt at kalde Report of Language Use for gengivet sprogbrug. Jeg mener, at det vil være nyttigt at anvende dette fænomen til undersøgelse af praktiserende læger og psykiateres sprogliggørelse af fagterminologi, fordi det kan give indsigt i, hvordan de to lægegrupper anvender en jargon, som er knyttet til deres professionelle identiteter og deres professionelle forståelser af depression. Report of Language Use kan betegnes som et supplement til det oprindelige spektrum af talegengivelseskategorier, men må i forhold til de øvrige kategorier betegnes som underbeskrevet, idet det eneste foreliggende studie af fænomenet udgøres af McIntyre et al.s undersøgelse i form af en kvantitativ optælling. For at anvende gengivet sprogbrug som adgang til at undersøge forståelser af depression er det derfor nødvendigt at præcisere fænomenets realisering og funktion: Hvilke sproglige valg foretager lægerne, når de anvender gengivet sprogbrug, og hvilke tolkninger lægger disse valg op til? For at kunne beskrive betydningen af de sproglige valg gør jeg brug af den systemisk funktionelle lingvistik. Her betragtes sproget som en ressource, hvor de grammatiske valg, der foretages i forbindelse med realiseringen af en ytring, i sig selv er bærere af betydning: "Det er således vigtigt, at vi holder os valget for øje, når vi betragter sprogbrug. En sprogbrug skabes ved, at afsender vælger at instantiere en del af sin ressource frem for andre dele. Den sprogbrug, som modtager møder, skal derfor ikke kun forstås i lyset af det valgte, men også i lyset af alt det, som afsender kunne have valgt at instantiere.” (Andersen og Holsting 2015: 16). På den måde er det ikke kun tematikken i den gengivne sprogbrug, der er central og meningsbærende, men i lige så høj grad de sproglige strukturer, hvormed talen om depressionssprog realiseres. Det er denne optik, jeg lægger ned over de forekomster af gengivet sprogbrug, som de to lægegrupper producerer. Min undersøgelse vil derfor også danne afsæt for en diskussion af, hvilket forklaringspotentiale gengivet sprogbrug - og mere specifikt gengivelse af habituel sprogbrug - rummer til at belyse problemstillinger $i$ en professionel sundhedskommunikativ talesprogskontekst.

Selvom tale- og tankegengivelsesparadigmet opstod med henblik på at undersøge litterære tekster, inviterede man allerede tidligt til en bredere anvendelse: "... the tools which linguists in literature have develo- 
ped for (rhetorical) analysis might also be usefully used on texts not normally thought of as literary" (Short 1988: 62). Ud over McIntyre et al. (2004) foreligger der mig bekendt ikke andre studier, hvor denne tilgang anvendes på talesprog, og dette på trods af, at Shorts udtalelse ligger 30 år tilbage.

\section{Tidligere studier af sundhedskommunikation}

Størstedelen af forskningen i sprogvidenskabeligt funderede studier af sundhedskommunikation tager udgangspunkt i interaktionen mellem læge og patient, dvs. hvordan lægen taler med patienten (Davidsen og Fogtmann 2014, Fogtmann og Davidsen 2014, se også oversigten i Nielsen 2010). Tilgangen er som regel konversationsanalytisk med fokus på identitets- og forståelsesarbejde i et sekventielt perspektiv ( $\mathrm{fx}$ Sacks et al. 1974, Heritage og Maynard 2006). En anden tilgang er kritisk diskursanalyse, der fokuserer på, hvordan prædefinerede magtstrukturer udspiller sig i en given interaktionel kontekst (Fairclough 1989, Wodak 1997). I modsætning hertil udgør denne artikel derfor et bidrag til belysning af sundhedskommunikation, hvor læger og psykiatere taler om depression og depressive patienter. Hvordan der tales om depression og om patienter med depression, har primært været undersøgt af andre faggrene som fx medicin og psykologi (fx Chew-Graham et al. 2000, Davidsen 2008, Dowrick 2009, Davidsen og Reventlow 2011). Et studie af Davidsen og Fosgerau (2014) baserer sig på de samme interviewdata som min undersøgelse og behandler, hvordan de to lægegrupper opfatter depressionsdiagnosen og den diagnostiske proces. Davidsen og Fosgerau anvender metoden Interpretative Phenomenological Analysis (IPA), som er anvendelig til indkredsning af centrale emner på et overordnet tematisk niveau (Smith et al. 2009). Hvor IPA-metoden i udgangspunktet er eksplorativ, er min tilgang $i$ højere grad deduktiv, idet jeg søger at indkredse et på forhånd afgrænset fænomen. Begge metoder kan altså håndtere større mængder af data, men indkredser så at sige genstandsobjektet på forskellig vis og med forskellig størrelse lup. Til sidst $\mathrm{i}$ artiklen vender jeg tilbage til en metodologisk diskussion af min tilgang til at undersøge gengivet sprogbrug i en grammatisk talesprogsramme. 


\section{UNDERSØGELSE AF GENGIVET SPROGBRUG HOS PRAKTISERENDE LÆGER OG PSYKIATERE}

Nærværende studie af gengivet sprogbrug viser, at de praktiserende læger lægger mere afstand til psykiatriens fagterminologi end psykiaterne selv. Det ses i brugen af modificering samt hvilke grammatiske subjekter der tilskrives ansvar for brug af fagtermerne. Inden præsentationen af resultaterne vil jeg gennemgå undersøgelsens data, teoretiske ramme og metode.

\section{DATA}

Data består af 23 semistrukturerede enkeltpersonsinterview. Af de 23 informanter er 11 psykiatere og 12 praktiserende læger, med en geografisk fordeling på to forskellige danske regioner. Aldersspredningen i de to lægegrupper er sammenlignelig, idet psykiaternes aldersspænd er 45-62, mens det for de praktiserende læger er 43-66. Interviewene er udført af lektor og speciallæge i almen medicin Annette Davidsen, som også har erfaring fra den psykiatriske sektor. Intervieweren anvendte en interviewguide med åbne spørgsmål med det formål at invitere de to lægegrupper til at tale om deres forståelse af depression samt om deres erfaringer med den diagnostiske proces i det kliniske arbejde (Davidsen og Fosgerau 2014: 3). Intervieweren og informanterne havde hverken privat eller professionelt forudgående kendskab til hinanden. Interviewene, som er bevaret i form af lydoptagelser, varer hver især 35-56 minutter og fandt sted på den enkelte læges arbejdsplads.

\section{TEORETISK OG METODISK RAMME}

Kontinumbaseret tale- og tankegengivelse

Interessen for gengivelse af tale og tanke har en lang litterær tradition bag sig. I nyere tid tæller væsentlige bidragsydere blandt andet Bakhtin (1984), Voloshinov (1930/1973), Fludernik (1993), Cohn (1978), Banfield (1982) og Leech og Short (1981). Leech og Shorts Style in Fiction (1981), der placerer sig i feltet 'litterær stilistik', introducerede med inspiration fra McHale (1978) en teori om tale- og tankegengivelse, der tager udgangspunkt i fortællerens mulighed for at gengive noget, der 
tidligere er blevet sagt, tænkt eller skrevet på en række forskellige måder. Denne mulighed materialiserer sig i en række forskellige kategorier af gengivelse. Alt efter valg af gengivelsesform præsenteres det gengivne mere eller mindre direkte for modtageren. De forskellige kategorier illustreres ved hjælp af et kontinuum, der spænder fra den mest direkte gengivelse til den mest opsummerende gengivelse. Formålet med dette kontinuum af gengivelse er ifølge Leech og Short muligheden for at graduere fortællerens rolle: "... as we move along the cline of speech presentation from the more bound to the more free end, his interference seems to become less and less noticeable, until [...] he apparently leaves the characters to talk entirely on their own" (Leech og Short 1981: 324). Følgende konstruerede eksempel illustrerer denne graduering:

Emma spurgte Anna: Hvad er dit yndlingsfag?

-Direkte tale: "Det er helt sikkert matematik, der er mit yndlingsfag", svarede Anna.

- Dakket direkte tale: Anna svarede, at det helt sikkert var matematik, der var hendes yndlingsfag.

- Indirekte tale: Anna svarede, at matematik var hendes yndlingsfag.

- Gengivelse af talehandling: Anna svarede Emma.

- Gengivelse af stemme: Anna talte med Emma.

I den direkte tale får vi den ordrette gengivelse af Annas svar til Emma. De næste kategorier præsenterer gengivelsen gradvist mindre direkte, og i kategorien gengivelse af stemme får vi blot at vide, at de to piger har talt sammen, uden adgang til hverken ordlyd eller talehandlingens karakter.

Teorien er senere blevet udviklet og justeret ad flere omgange, dog altid med skreven tekst som genstandsobjekt (Short 1996, Semino og Short 2004). I forlængelse heraf foreligger der et enkelt studie, hvor det Leech og Short-funderede tale- og tankegengivelsesapparatet anvendes på talt sprog (McIntyre et al. 2004). Studiet havde form af en korpusundersøgelse, hvor kategorierne fra det oprindelige tale- og tankegengivelsesspektrum blev operationaliseret i talesprog. I denne proces opstod behovet for en ny kategori, Report of Language Use, til 
at indfange gengivelse af habituelt sprog, ofte anvendt af en bestemt talergruppe, som (1) og (2) er eksempler på. I mit møde med de praktiserende læger og psykiaternes refleksioner over depression i interviewene bemærkede jeg en tendens hos begge lægegrupper til at gengive habituel sprogbrug, og det er denne variant af gengivet sprogbrug, der vil blive udfoldet på de kommende sider.

\section{Gengivet sprogbrug}

McIntyre et al. beskriver gengivet sprogbrug på følgende måde: "RU [Report of Language Use; HSP] captures metalinguistic mentions of language use, such as the words or expressions habitually used to refer to things, or the ways words were spelled or pronounced" (McIntyre et al. 2004: 519). Som påpeget i introduktionen er gengivet sprogbrug kun beskrevet sparsomt i McIntyre et al.s studie af tale- og tankegengivelse i talesprog, og deres definition udgøres af det gengivne citat ovenfor, ligesom de andetsteds tilføjer, at brugen ofte er idiosynkratisk og ofte optræder i forbindelse med redegørelser om fortiden (McIntyre et al. 2004: 517). Derfor er afgrænsningskriterierne temmelig uklare. Min måde at afgrænse gengivet sprogbrug på kan derfor påvirke sammenligneligheden med McIntyre et al.s studie. Den sparsomme redegørelse åbner dog også op for et todelt perspektiv: For det første giver det mulighed for at beskrive kategorien mere fyldestgørende, hvilket nærværende studie er et bidrag til. For det andet giver det mulighed for at gøre kategorien operationel i en grammatisk ramme til undersøgelsen af forståelser af depression. Ud over at typificere realiseringerne af gengivet sprogbrug på baggrund af mine data har jeg derfor fundet det brugbart at inddrage mere klassiske, sprogvidenskabelige undersøgelsesparametre såsom modalitet og brug af pronomener i operationaliseringen af gengivet sprogbrug som metodisk ramme til undersøgelse af depressionsforståelser. Det følgende afsnit indeholder en indkredsning af gengivet sprogbrug samt mine annoteringsprincipper, hvorefter jeg vil præsentere undersøgelsens resultater. 


\section{ANNOTERING AF GENGIVET SPROGBRUG}

I annoteringen har jeg optalt alle forekomster af gengivet sprogbrug $\mathrm{i}$ interviewene, hvilket betyder, at der ikke er foretaget en decideret afgrænsning af den enkelte forekomst i forhold til temaet 'depression'. Argumentet for min annotering af alle forekomster af gengivet sprogbrug har været, at tematikken for samtalen har været rammesat af interviewets formål, nemlig at undersøge forståelser af depression, som beskrevet $\mathrm{i}$ afsnittet om undersøgelsens datamateriale. Efter annoteringen er alle forekomster gennemgået for at sikre, at der ikke optræder fx ekskurser, som ikke relaterer sig til interviewets overordnede samtaleemne, depression. Jeg vil vende tilbage til de metodiske implikationer af denne tilgang i artiklens diskussionsafsnit. Min tilgang til at studere forståelser af depression er datadrevet, idet jeg har valgt at lave optællinger af gengivet sprogbrug og de grammatiske realisationer, der knytter sig hertil, og dernæst teste resultaterne for signifikans, enten ved brug af en chi $^{2}$-test eller en Fischer exact-test i de tilfælde, hvor antallet af forventede forekomster er under 5. De grammatiske kategorier, som jeg baserer min undersøgelse af gengivet sprogbrug på, er udvalgt ved at gennemgå samlingen af forekomster og på den baggrund identificere iøjnefaldende grammatiske træk, som fx modalitet.

\section{Hedde og kalde}

Eksempel (2) ovenfor ('de der gamle endogene som det hed i gamle dage') illustrerer en prototypisk forekomst af gengivet sprogbrug, hvor taleren anvender kopulaverbet bedde til at gengive sprogbrug om depression. En anden hyppigt forekommende brug er den kausative konstruktion kalde:

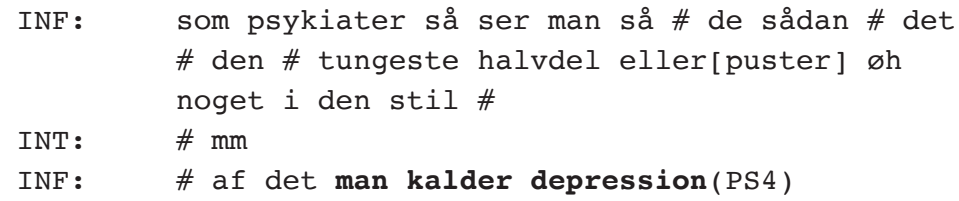

De to typer af gengivet sprogbrug i (2) og (3) dækker langt størstedelen af realiseringerne i mine data, og disse to varianter vil derfor udgøre 
omdrejningspunktet for den videre undersøgelse af gengivet sprogbrug. Forskellen på de to konstruktioner er agens: Kopulakonstruktionen med hedde i (2) fordrer ingen agent. Denne agentløse konstruktion implicerer en høj grad af objektivitet, som gør, at gengivet sprogbrug i denne realisering kan præsenteres som et faktum, der synes verificerbart. Inden for den systemisk funktionelle lingvistik er hedde et eksempel på en relational proces, der markerer tilstand frem for $\mathrm{fx}$ handling (Halliday og Matthiessen 2004: 210ff.). Typen af proces eller verbum samt fraværet af en agent gør altså denne variant mere statisk i sin semantik. Eksemplet med kalde i (3) er derimod en kausativ konstruktion (Hansen og Heltoft 2011: 866-867, Andersen og Holsting 2015: 166). I modsætning til hedde realiseres den kausative konstruktion med en agent og dermed en synlig (og ved passivkonstruktioner en underforstået) agent. Ved at anvende kalde i forbindelse med gengivet sprogbrug har taleren derved, afhængigt af valg af subjekt, mulighed for fx at markere distance eller tilhørsforhold til den introducerede terminologi. Mens eksempel (2) ikke har nogen eksplicit agent, er eksempel (3) realiseret med agenten man. Jeg vil i de følgende afsnit præsentere resultaterne for brugen af hedde og kalde og diskutere implikationerne af disse to realisationer af gengivet sprogbrug i forhold til forståelser af depression. Inden da vil jeg gennemgå de kriterier, jeg har anvendt i afgrænsningen af gengivet sprogbrug.

\section{Afgransning af gengivet sprogbrug}

I datamaterialet forekommer eksempler, som har en vis lighed med brugen af hedde præsenteret $\mathrm{i}(2)$, men som opfylder en anden funktion $\mathrm{i}$ interviewene, nemlig at genkalde sig ord eller vendinger:

(4) men der står faktisk så i i hvad hedder det i: \# i vores henvisnings:- øh \# hvad hedder så noget \# -procedure der at \# det faktisk skal være foretaget hos egen læge \# før de henviser (PS6)

I (4) lader taleren til ikke at kunne huske navnet på de retningslinjer, han ønsker at referere til. Han producerer tøven ('i:', 'henvisnings:-'), adskillige pauser (\#) og selvafbrydelser, som optræder både i starten ved introduktionen af præpositionsfrasen ('i i hvad hedder det i:') og 
som indskudt ordsøgning ved det sammensatte navneord, han prøver at genkalde sig. Derved får ytringen en genkaldelsesfunktion, som er realiseret af en interrogativstruktur ('hvad hedder det', 'hvad hedder sådan noget'). Denne type metalingvistisk modificering er relateret til ordsøgning og reparatur. Brugen af hedde har altså i denne sammenhæng som sådan ingen referentiel værdi og medregnes derfor ikke i optællingen. Andre ikkeinkluderede grænsetilfælde indbefatter forekomster, hvor hele sætninger optræder som citatlignende gengivelser:

(5) altså \# indgangsbilletten til at komme ind på psykiatrisk \# sygehus i [navn på hospital]! \# det hedder jeg har selvmordstanker \# (PS2)

I (5) fremsætter taleren en generisk eksemplificering af adgangskravene for hospitalsbehandling, hvor forekomsten af hedde anvendes til at introducere et generelt udsagn. Brugen af hedde får udsagnet til at minde om gengivet sprogbrug. Dog mener jeg, at idet der fremsættes en hel sætning, 'jeg har selvmordstanker', er der ikke tale om brug af en term, men snarere om direkte tale i generisk form (Clark og Gerrig 1991, Tannen 1996, Rathje 2011).

I processen med at identificere forekomster af gengivet sprogbrug er jeg stødt på to typer, der er umiddelbart relateret til interaktionen mellem interviewer og informant, og hvor begge samtaledeltagere, omend i forskellig grad, bidrager til konstruktionen af gengivet sprogbrug. Motivationen for at nævne disse sjældnere forekomster er at pege på alsidigheden i realiseringen af gengivet sprogbrug, ikke mindst set $\mathrm{i}$ forhold til McIntyre et al.s sparsomme redegørelse. Denne indledende beskrivelse kan forhåbentlig fungere som udgangspunkt for en mere fyldestgørende redegørelse af gengivet sprogbrug. Jeg mener, at sådanne finkornede interaktionelle analyser vil kunne have betydning for videre studier, der ønsker at undersøge kontekstuelle faktorer såsom interviewerens påvirkning af informantens tale i produktionen af specifikke sproglige fænomener, i dette tilfælde gengivet sprogbrug. I denne undersøgelse har jeg i min optælling kun medtaget de forekomster, hvor det er informanten, der producerer det egentlige gengivne begreb. I (6) er det intervieweren, der ved at foreslå mærkatet depression 
producerer en forekomst af gengivet sprogbrug. Informantens svar indeholder imidlertid ingen ord, der står materialiter, og derfor har jeg valgt ikke at inkludere sådanne forekomster:

(6) INT: nej \# så \# så det er nogle tilstande du egentlig ville kalde depression \# ud fra kriterierne eller hvordan \#

INF: \# ja de kunne sa- altså de passer på kriterierne (PL11)

En anden variant af interaktionelt affødt gengivet sprogbrug er følgende:

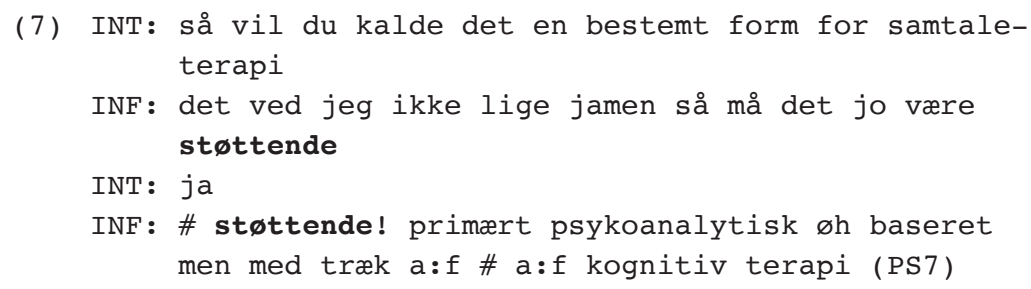

I modsætning til eksemplet i (6) er det i (7) informanten selv, der producerer det ord, der står materialiter (stottende). Både (6) og (7) er således eksempler på interaktionelt affødte og samkonstruerede forekomster, men hvor brugen af materialiter er placeret forskelligt. Selvom man ud fra et interaktionsperspektiv kan argumentere for, at alle forekomster i større eller mindre grad er interaktionelt affødte, er eksempler som (6) ikke inkluderet, hvorimod jeg har valgt at anskue eksempler som (7) som gengivet sprogbrug, da den del, der står materialiter, er produceret af informanten, og det i dette studie er informantens brug af fænomenet, der er i fokus. En tredje variant af gengivet sprogbrug er en realisering i substantivisk form:

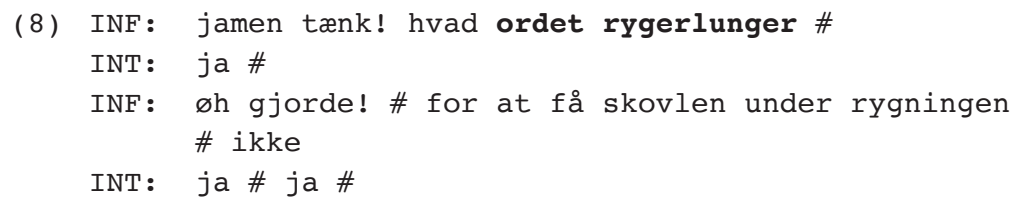




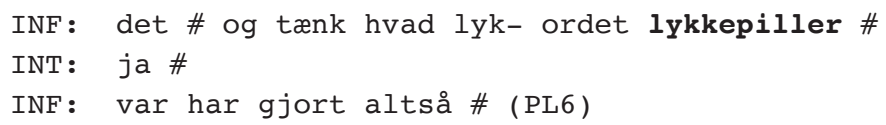

Denne substantiviske realisering af gengivet sprogbrug er relativt sjælden i mit datasæt. En adjektivisk variant, som er realiseret med såkaldt, optræder kun en enkelt gang. Ligeledes optræder den variant, som jeg har valgt at kalde mental gengivet sprogbrug, hvor den gengivne sprogbrug realiseres med lare, kun i ét tilfælde:

(9) og øh \# og øh \# problemet er jo lidt \# at øh \# at det er svært at skelne \# \# øh \# hvad der e:r \# hvad der er \# øh er det vi lærte som en endogen depression og \# og hvad de:r mere er \# stress og \# og øh \# og øh eksistentielle \# vilkår (PL4)

\section{RESULTATER}

Af tabel 1 fremgår forekomster og procenttal af gengivet sprogbrug $i$ de to lægegrupper.

TABEL 1. HYPPIGHED OG DISTRIBUTION AF GENGIVET SPROGBRUG I DE TO LÆGEGRUPPER

\begin{tabular}{lcccc}
\hline \multirow{2}{*}{ Variant } & \multicolumn{2}{c}{ Praktiserende læger } & \multicolumn{2}{c}{ Psykiatere } \\
& $\mathrm{N}$ & $\% 1 \%$ & $\mathrm{~N}$ & $\%$ \\
\hline Hedde & 38 & $41 \%$ & 21 & $42 \%$ \\
Kalde & 31 & $0 \%$ & 2 & $44 \%$ \\
Interaktionel & 0 & $7 \%$ & 4 & $4 \%$ \\
Substantivisk & 5 & $0 \%$ & 1 & $8 \%$ \\
Adjektivisk & 0 & $1 \%$ & 0 & $2 \%$ \\
Mental & 1 & $100 \%$ & $\mathrm{n}=48$ & $100 \%$ \\
\hline Total & $\mathrm{n}=75$ & &
\end{tabular}

Frekvensen af gengivet sprogbrug i de to grupper viser, at de praktiserende læger i højere grad end psykiaterne gør brug af denne ressource (75 versus 48 forekomster). Det samlede antal ord i gruppen af praktiserende læger udgør 96.854, mens tallet i psykiatergruppen er 82.104. 
En indeksudregning viser, at forekomster af gengivet sprogbrug per 1000 ord for de praktiserende læger er 0,77, mens tallet i psykiatergruppen er 0,58 forekomster. Denne forskel antyder, at de praktiserende læger oftere vælger at italesætte depressionsterminologien, hvilket kan skyldes, at retningslinjerne og diagnosekriterierne for behandling af depression er formuleret i psykiatrien (Davidsen og Fosgerau 2014: 1). Derfor anskuer de praktiserende læger muligvis depressionslidelsen som ukendt eller fremmed territorium, og brugen af gengivet sprogbrug kommer således til at fungere som en måde, hvorpå denne lægegruppe indfanger dette, set i forhold til psykiaterne, relativt ukendte territorium. Jeg vil udfolde denne antagelse i de kommende afsnit ved at knytte an til, at de to gruppers sproglige valg tyder på forskellige forståelser af depression. Det følgende analyseafsnit omhandler, hvordan hedde og kalde bliver brugt af de to talergrupper.

\section{Hedde og kalde}

En chi $^{2}$-test for den overordnede brug af hedde versus kalde viser ingen signifikant forskel på de to lægegrupper $(\mathrm{p}=0,4085)$. Dette resultat indikerer, at brugen af henholdsvis hedde og kalde ikke tilhører en specifik professionel gruppe. Betyder denne næsten ligelige fordeling af begge varianter i de to lægegrupper imidlertid, at de to typer af læger introducerer og anvender depressionsbegreber på samme måde og dermed forholder sig til depressionsbegreber som givne og objektivt verificerbare størrelser, som bedde-varianten kan siges at implicere? For at besvare dette spørgsmål har jeg undersøgt et andet fænomen i de to gruppers brug af gengivet sprogbrug, nemlig hvilke grammatiske subjekter der hæftes på præsentationen af gengivet sprogbrug.

\section{Hvem tilhorer den gengivne sprogbrug?}

Jeg har i min analyse af gengivet sprogbrug fundet det nyttigt at undersøge, hvem den gengivne sprogbrug tilhører, dvs. hvem der anføres som udsiger af sprogbrugen. Forskellen på de to hovedvarianter af gengivet sprogbrug er som nævnt agens: Hedde er en kopulakonstruktion, som realiseres uden agent:

(10) INF: og så er der noget der hedder mindfulness som er 
INT: ja

INF: \# ved at komme på mode nu \# altså (PS4)

Kalde er derimod en kausativ konstruktion, som er agensstyret:

(11) vi ser meget! få \# sådan hvad jeg vil kalde \# klassiske depressioner (PL6)

Den agensløse konstruktion $\mathrm{i}$ hedde betyder, at en analyse af udsiger $\mathrm{i}$ denne variant af gengivet sprogbrug ikke er mulig. Ved kalde angives tilhørsforholdet ved brug af pronomener, som falder i følgende fire grupper: 1. person singularis, 3. person singularis samt 1. og 3. person pluralis. Forekomsterne af kalde fordelt på de forskellige typer pronomener er gengivet i tabel 2 :

TABEL 2. FOREKOMSTER AF PRONOMENER I KALDE

\begin{tabular}{lcccc}
\hline & \multicolumn{2}{c}{ Praktiserende læger } & \multicolumn{2}{c}{ Psykiatere } \\
& $\mathrm{N}$ & $\%$ & $\mathrm{~N}$ & $\%$ \\
\hline Jeg & 11 & $35,4 \%$ & 2 & $9,5 \%$ \\
Man & 7 & $22,5 \%$ & 11 & $52,3 \%$ \\
Vi & 11 & $35,4 \%$ & 7 & $33,3 \%$ \\
De & 2 & $6,4 \%$ & 1 & $4,7 \%$ \\
\hline Total & $\mathrm{n}=31$ & $99,7 \%$ & $\mathrm{n}=21$ & $99,8 \%$ \\
\hline
\end{tabular}

Jeg

11 af de praktiserende lægers forekomster af gengivet sprogbrug er realiseret med jeg. I (12) anvender en praktiserende læge denne subjektive markering i forbindelse med kalde:

(12) \# øh \# jamen: \# jeg laver da noget ha jeg selv kalder kognitiv terapi (PL2)

Hos psykiaterne optræder jeg derimod kun 2 gange. (13) illustrerer en psykiaters brug af jeg: 


$$
\text { Jeg laver - det - jeg kalder det samtaleterapi (PS7) }
$$

En chi ${ }^{2}$-test viser en signifikant forskel i brugen af jeg i de to lægegrupper $(\mathrm{p}=0,0339)$ og peger dermed på, at de praktiserende læger i højere grad end psykiaterne taler ud fra et personligt perspektiv i gengivet sprogbrug om depression. Jeg vil uddybe denne tendens til subjektiv markering $i$ analysen af 1 . person pluralis, $v i$.

\title{
Man
}

Det generiske pronomen man anvendes, når en taler ønsker at generalisere en given ytring:

\begin{abstract}
By using a generic pronoun the speaker is instructing the addressee to see the referent from a "structural" point of view: Even though it may in principle be possible to determine the pronoun's precise extension, the whole point is that the predication illustrates how the world works in general, not the properties of specific persons or events. (Jensen og Gregersen 2016: 6)
\end{abstract}

Pronomenet $d u$ kan også fungere som generisk pronomen, men er ikke nær så hyppig som man (Jensen og Gregersen 2016: 1). Jensen og Gregersen diskuterer i deres artikel semantiske og interaktionelle forskelle på man og $d u$ og fremhæver $d u$ som et stilistisk greb, som kan bruges til at vise snarere end at fortælle en given pointe, ligesom de fremhæver, at brugen af $d u$ synes at være kontekstsensitiv (Jensen og Gregersen 2016: 5). Kun man optræder som generisk pronomen i mine forekomster af gengivet sprogbrug. Konteksten for min undersøgelse er forskningsinterviewet, hvor formålet er at indsamle specialiseret viden inden for et felt, i dette tilfælde depression. Rammen for de to lægegruppers produktion af gengivet sprogbrug kan dermed betegnes som institutionel og professionel og med en høj grad af seriøsitet, hvilket kunne forklare, at begge lægegrupper foretrækker man frem for $d u$ som generisk pronomen. Dog er hyppigheden af man i de to lægegrupper forskellig: Under en fjerdedel ( 7 af 31 forekomster) af kalde hos de praktiserende læger realiseres ved hiælp af man, mens det er godt halvdelen hos psykiaterne (11 ud af 21). Tendensen til forskellig brug af generisk markering bekræftes af en chi $^{2}$-test, som viser en 
markant signifikant forskel mellem de to lægegrupper i brugen af man $(0,026668)$. I (14) refererer psykiateren implicit til en tidligere brug af depressionsjargon:

(14) ej diagnostisk kalder man det ikke mere (PS5)

Samtidig udtrykker psykiateren i (14), at denne brug ikke længere er den korrekte. I stedet for eksempelvis subjektivt at markere, hvilken terminologi han selv foretrækker i stedet for diagnostisk, anvendes i stedet man til at fremhæve dette skift i brug af terminologi. Denne brug af man knytter an til en generisk sandhedsværdi (Jensen og Gregersen 2016), som herved understøtter psykiaterens argumentation. I denne sammenhæng er det igen interessant at bemærke, at diagnosekriterierne for depression er formuleret i psykiatrien (Davidsen og Fosgerau 2014: 1). Psykiaternes tendens til at omtale depression med en høj grad af generisk sandhedsværdi kunne indikere, at denne gruppe i højere grad orienterer sig mod denne, i psykiatrien, veldefinerede forståelse af depression. Psykiaternes signifikante valg af man vil blive uddybet i det senere afsnit om brugen af modalitet $i$ gengivet sprogbrug. Hvor de praktiserende læger synes at hælde mod den personlige frem for den generiske markering i gengivet sprogbrug om depression, som vi så $\mathrm{i}$ resultatet for brugen af jeg, forekommer tendensen hos psykiaterne altså at være omvendt.

\section{Vi}

Brugen af $v i$ er kendetegnet ved at inkludere flere stemmer og andre end blot talerens egen. Pronomenet anvendes for eksempel til at markere tilhørsforhold, hvilket kan foregå ved at inkludere personer, der ikke nødvendigvis er til stede i ytringssituationen:

(15) jeg tror at at altså \# d- det det jeg sådan måske \# bruger allermest \# det er det vi kalde:r \# psykoedukation \# (PS4)

$V i$ kan også anvendes til at inkludere tilhøreren: 
(16) så i så fald kan vi kalde dem belastningsreparatio- \# øh \# d- reaktioner med depressive symptomer (PS2)

Optællingen af 1 . person pluralis viser en ligelig fordeling af denne variant i de to lægegrupper, og en $\mathrm{chi}^{2}$-test viser ingen signifikant forskel på hyppigheden af de praktiserende lægers og psykiaternes brug af pronomenet ( $\mathrm{p}=0,872926)$. Hvis vi kigger nærmere på brugen af vi, er referenterne i de to lægegrupper imidlertid af forskellig karakter: I 5 ud af 7 tilfælde hos psykiaterne refererer $v i$ til psykiaterne som lægefaglig profession, som fx i (15). De resterende to forekomster inkluderer muligvis tilhøreren, som i (16), hvor vi synes at markere enighed. I kun 2 ud af 11 tilfælde hos de praktiserende læger optræder $v i$ som entydig reference til de praktiserende læger som professionel gruppe. (17) er et eksempel på denne brug af vi hos de praktiserende læger:

(17) jeg har svært ved at \# øh jeg vil ikke sige acceptere øh men men sådan ligesom forbinde! \# den psykiatriske måde at se depression på som jeg kan huske fra de: fra psykiatriske afdelinger \# til den! måde vi ser depressioner \# eller det vi kalder depression øh herude i praksis (PL7)

7 af 11 forekomster af $v i$ hos de praktiserende læger har en potentielt inkluderende funktion af andre aktører end de praktiserende læger selv, som fx i (18), hvor vi refererer til læge-patient-relationen:

(18) så skal vi jo sammen vælge! om \# om vi kalder det angst eller depression (PL4)

Ud fra denne mere detaljerede undersøgelse af brugen af 1. person pluralis viser det sig, at de praktiserende læger bruger vi mere varieret end psykiaterne til at favne en række forskellige tilhørsforhold og relationer, hvor et bredt spektrum af stemmer og aktører sættes i spil. Hos psykiaterne anvendes $v i$ primært som reference til psykiaternes profession. Denne lægegruppe fremsætter altså i højere grad end de praktiserende læger en entydigt identificerbar stemme, som kunne vidne om en mere etableret professionel identitet. 
Sammenfattende viser resultaterne for brugen af pronomener, at 1. person singularis er mere udbredt hos de praktiserende læger end hos psykiaterne, mens det modsatte er tilfældet $i$ brugen af 3. person singularis, man. 1. person pluralis har en jævn fordeling mellem de to grupper; dog viser en analyse af referenterne en markant forskel i brug. I den samlede diskussion til sidst vil jeg uddybe fundene i forhold til forståelser af depression i de to lægegrupper. Inden da vil jeg præsentere resultaterne for markering af modalitet i den gengivne sprogbrug.

\section{Modalitet $i$ gengivet brugbrug}

For at nuancere anvendelsen af gengivet sprogbrug har jeg undersøgt brugen af modalitet hos de to lægegrupper. Modalitet markerer den usikkerhed, der befinder sig mellem i spændet mellem rent positive (bekræftende) eller rent negative (benægtende) ytringer: "Modalitet betegner afsenders attitude $\mathrm{i}$ forhold til den propositionelle/proposale betydning i den afsendte ytring [...] afsender kan så graduere sit udsagn eller spørgsmål ved at specificere grader af muligheder og sandsynligheder og/eller vanlighed." (Andersen og Smedegaard 2005: 63). En analyse af modalitet giver altså mulighed for at undersøge, $i$ bvor høj grad taleren enten tilslutter sig eller stiller spørgsmålstegn ved den gengivne sprogbrug. (19) illustrerer hedde med modalitet, der her markerer sandsynlighed ved hjælp af modalpartiklen vel:

(19) jamen det er vel det der hedder depression nu ikke \# (PL7)

Et andet eksempel på modalitet optræder i (20), hvor psykiateren udtrykker usikkerhed om den rigtige term, karakterneurotiske:

(20) INF: og jeg tror \# hvis jeg s- tænker \{med livet\} på den der psykiatriske afdeling der havde de måsvar de måske lidt neurotiske eller \# hvad hed \{de\} karakte- \# karakterneurotiske! hed hed det ikke så nogle \#

INT: \# ja \# ja

INF : \# $\varnothing \mathrm{h}$ dengang \# 
I (20) markeres usikkerhed gennem interrogativstrukturen, der fungerer som en henvendelse til intervieweren. Derudover tilskriver præteritumsformen referentiel værdi ('var det ikke sådan, det hed engang?'). (20) har visse lighedspunkter med (4), hvor informanten brugte bedde til genkaldelse og ordsøgning ('men der står faktisk så i i hvad hedder det i: \# i vores henvisnings:- øh \# hvad hedder så noget \# -procedure der'). Her argumenterede jeg for, at brugen af hedde var uden referentiel værdi. I (20) er henvendelsen til intervieweren af mere direkte karakter, idet ikke anvendes som en markør, der lægger op til modpartens bekræftelse. Brugen af hedde i (20) fungerer derfor i højere grad end eksemplet i (4) som et spørgsmål og falder dermed ind under den systemisk funktionelle definition af modalitet. Resultaterne for gengivet sprogbrug med modalitet er vist i tabel 3:

TABEL 3. MODALITET I GENGIVET SPROGBRUG

\begin{tabular}{lrrrr} 
& \multicolumn{2}{c}{ Praktiserende læger } & \multicolumn{2}{c}{ Psykiatere } \\
& $\mathrm{N}$ & $\%$ & $\mathrm{~N}$ & $\%$ \\
\hline Med modalitet & 36 & $52 \%$ & 10 & $24 \%$ \\
\hline Total & $\mathrm{n}=69$ & $100 \%$ & $\mathrm{n}=41$ & $100 \%$ \\
\hline
\end{tabular}

En $\mathrm{chi}^{2}$-test for brugen af gengivet sprogbrug med og uden modalitet viser en stærkt signifikant forskel mellem de to grupper af læger $(\mathrm{p}=0,004283)$. De praktiserende læger synes altså at markere modalitet i gengivet sprogbrug i langt højere grad end psykiaterne. En forklaring kunne findes i psykiaternes specialistfunktion, hvor de ved at præsentere mærkater uden modalitet understreger en mere specialiseret og tydelig professionel identitet end den praktiserende læge. Derudover er det som nævnt psykiaterne, der har definitionsretten, hvad angår depression (Davidsen \& Fosgerau 2014: 1). Den sikkerhed, der markeres i psykiaternes fravalg af modalitet, understøtter Davidsen og Fosgeraus udlægning af psykiaternes position. Omvendt kan den markante brug af modalitet hos de praktiserende læger siges at skabe en distance eller tøven over for psykiatriens specialiserede terminologi. I forbindelse med hedde fordeler modaliteten sig på følgende måde i de to lægegrupper: 


\begin{tabular}{lcccc}
\hline \multirow{2}{*}{ Talergruppe } & \multicolumn{2}{c}{ Praktiserende læger } & \multicolumn{2}{c}{ Psykiatere } \\
& $\mathrm{N}$ & $\%$ & $\mathrm{~N}$ & $\%$ \\
\hline Med modalitet & 13 & $34 \%$ & 5 & $25 \%$ \\
Uden modalitet & 25 & $66 \%$ & 15 & $75 \%$ \\
\hline Total & $\mathrm{n}=38$ & $100 \%$ & $\mathrm{n}=20$ & $100 \%$ \\
\hline
\end{tabular}

Eksempel (2) viste, hvordan hedde anvendes uden modalitet til at introducere en term som et veletableret fænomen ('de der gamle endogene som det hed i gamle dage'). En chi ${ }^{2}$-test for brugen af modalitet i forbindelse med hedde viser ingen signifikant forskel mellem de to lægegrupper $(\mathrm{p}=0,47111)$. Hedde uden modalitet er anvendt hyppigere i begge grupper, hvilket kan skyldes selve kopulakonstruktionens semantik, der uden indbygget agens kan siges at udtrykke et mere statisk og dermed objektivt forhold, end det for eksempel er tilfældet med semantikken i kalde, der som nævnt implicerer en agent, til hvem sprogbrugen tilskrives. Resultaterne for modalitet i forbindelse med kalde er angivet $\mathrm{i}$ tabel 5:

TABEL 5. MODALITET I KALDE

\begin{tabular}{lcccc}
\hline \multirow{2}{*}{ Talergruppe } & \multicolumn{2}{c}{ Praktiserende læger } & \multicolumn{2}{c}{ Psykiatere } \\
& $\mathrm{N}$ & $\%$ & $\mathrm{~N}$ & $\%$ \\
\hline Med modalitet & 23 & $74 \%$ & 5 & $24 \%$ \\
Uden modalitet & 8 & $26 \%$ & 16 & $76 \%$ \\
\hline Total & $\mathrm{n}=31$ & $100 \%$ & $\mathrm{n}=20$ & $100 \%$ \\
\hline
\end{tabular}

I præsentationen af resultaterne for kalde, hvor agenten er central, så vi en næsten identisk fordeling i de to talergrupper, idet varianten udgjorde omtrent halvdelen af forekomsterne af gengivet sprogbrug $i$ hver talergruppe. Hvis vi skelner mellem kalde med og uden modalitet, ser vi imidlertid, at de praktiserende læger anvender modalitet i højere grad end psykiaterne. En chi ${ }^{2}$-test bekræfter denne markante forskel 
$(\mathrm{p}=0,000349)$. (21) er et eksempel på psykiaternes brug af varianten uden modalitet:

(21) INF: fordi nogle gange er det man: kalder depression jo ogs:å øh \# dårlig ægteskab og dårlig arbejdsplads $0: 9$

INT: \# ja \# ja \#

INF: \# vanskeligheder med børnene og

INT: \# ja \#

INF: \# altså \# så det er jo også vigtigt! man får set på hvad sygdom

INT: ja

INF : og hvad er livsomstændigheder (PS5)

I (21) taler psykiateren om praktiserende lægers tilgang til behandling af patienter med depression. Psykiateren introducerer termen depression uden nogen form for modalitet ('det, man kalder depression'). Brugen af det generiske pronomen man, som jeg tolker som en reference til de praktiserende læger, kunne indikere, at psykiateren finder, at depression anskues forkert af de praktiserende læger, som for ofte, ifølge psykiateren, har en misforstået tilgang til diagnosticeringen. På den måde fungerer kalde uden modalitet som psykiaterens evaluering af de praktiserende lægers tilgang til diagnosticering og behandling af depression, og hvor psykiateren ved anvendelse af man gør de praktiserende læger ansvarlige for en misforstået brug af diagnosen. Man synes altså her at blive brugt til at lægge distance til en bestemt sprogbrug, som i kombination med psykiaterens fravalg af modalitet synes at understrege de praktiserende lægers ukritiske brug af termen. Et eksempel på kalde med modalitet er eksemplet fra (18), som gengives nedenfor:

(22) så skal vi jo sammen vælge! om \# om vi kalder det angst eller depression (PL4)

Eksemplet udtrykker modaliteten mulighed, som markeres ved konjunktionen om. Denne italesættelse af mulighed kunne være en indikation

på en rummelig og fleksibel forståelse af depressionsterminologien og -diagnosen - og tilmed med en høj grad af patientinvolvering som 
udtrykkes ved, at den praktiserende læge fremstiller diagnosticeringsprocessen som en fælles beslutning mellem læge og patient. Der kan argumenteres for, at modaliteten ligestiller patientens egen mening med lægens professionelle ekspertise i beslutningsprocessen og samtidig nedtoner betydningen af den rette fagterminologi.

\section{DISKUSSION OG PERSPEKTIVER}

Forskellig anvendelse af gengivet sprogbrug som udtryk for forskellige forståelser af depression

Denne undersøgelse af gengivet sprogbrug har vist, at fænomenet realiseres på en række forskellige måder, og at de forskellige realiseringsmønstre i de to lægegrupper manifesterer forskellige forståelser af depression. Frekvensen af gengivet sprogbrug var højere hos de praktiserende læger. Den nærmere analyse indikerede imidlertid, at de praktiserende læger ikke forholder sig til depressionsterminologien som en definerende størrelse; snarere tyder den hyppige forekomst af modalitet og subjektivitet på, at depression er en størrelse, der kan personliggøres, forhandles og sættes spørgsmålstegn ved. Denne observation kan modstilles med psykiaternes anvendelse af gengivet sprogbrug som et generisk fænomen og med langt mindre modalitet. Groft skitseret kan man anskue psykiaternes anvendelse af gengivet sprogbrug som en autoritetsrettet top-down-forstålse af depression. Hos de praktiserende læger udmønter forståelsen sig i højere grad som en bottom-up-tilgang, der i mindre grad tager højde for normer og det faste forlæg, som findes i fx psykiatriens diagnosekriterier. I deres undersøgelse af de to lægegruppers forståelser af depression konkluderer Davidsen og Fosgerau blandt andet følgende: "Psychiatrists considered the diagnosis of depression as a pragmatic and agreed construct and they did not question its validity", hvorimod de praktiserende læger "... thought depression was a "gray area" and questioned the clinical utility in general practice" (Davidsen og Fosgerau 2014:1). Den signifikante forskel i brugen af modalitet i kalde i de to lægegrupper kan siges at udgøre et strukturelt belæg for Davidsen og Fosgeraus observerede forskelle i de to lægegruppers syn på depression som enten et veldefineret fænomen eller en mindre velafgrænset størrelse. 
En af hovedkonklusionerne i pronomenanalysen var, at de praktiserende læger tager afsæt $i$ en personlig eller subjektiv forståelse gennem brugen af jeg, hvorimod psykiaternes markering i højere grad er generisk, hvilket afspejles i gruppens hyppige brug af man, både set i forhold til gruppens egen brug af jeg og de praktiserende lægers brug af man. I 1. person pluralis synes psykiaternes ensartede brug af pronomenet at understrege deres professionelle tilhørsforhold, mens pronomenet hos de praktiserende læger sprogligt manifesterer en bredere vifte af potentielle aktører og ressourcer, som kan indtænkes i vurderingen af behandlingen af den depressive patient. Denne bredde i aktører kan tilmed ses som et udtryk for et patientsyn, der rummer patienten som et helt menneske i en socialt forankret kontekst, hvor baggrund og livsomstændigheder anskues som afgørende faktorer i lægens vurdering af patientens lidelse (fx Armstrong og Earnshaw 2004, Schumann et al. 2012). Psykiaternes mere diagnostiske fokus, som blandt andet manifesteres i depersonaliseret genericitet, kan siges at træde i stedet for den diversitet og forhandling, som er sprogligt identificerbar hos de praktiserende læger.

Davidsen og Fosgerau diskuterer på baggrund af deres resultater mulige implikationer for samordnet behandling i sundhedssektoren og konkluderer blandt andet, at "GPs [general practitioners; HSP] feel that psychiatrists have the right of definition, which could possibly lead to a clash of interests" (Davidsen og Fogtmann 2014: 8). Dette studie er et bidrag til at identificere, hvordan variationer i realiseringen af gengivet sprogbrug i de to lægegrupper kan ses som et udtryk for håndteringen af denne definitionsret.

\section{Hvad kan den grammatiske talesprogsanalyse give til sundhedsvidenskaben - og vice versa?}

Davidsen og Fosgerau har som nævnt i introduktionen anvendt metoden Interpretative Phenomenological Analysis (IPA) i deres undersøgelse. IPA er velegnet til afdækning og gruppering af større mængder af kvalitative interviewdata på en måde, som min grammatisk funderede tilgang ikke rummer potentialet for. Det skyldes blandt andet, at IPAmetoden bevæger sig på et tematisk niveau. Den grammatiske analyse er derimod i stand til at beskrive konkrete sproglige strukturer og der- 
med give en mere detaljeret beskrivelse af et givent fænomen, hvilket analysen af gengivet sprogbrug kan ses som et eksempel på. Davidsen og Fosgerau påpeger om psykiaternes og de praktiserende lægers sprogbrug:

The two groups differed completely in their use of language when talking about depression and patients with depression. Psychiatrists used medical language and focused almost solely upon symptoms of depression and the agreed diagnostic criteria for the diagnosis. They talked in general terms about groups of patients and GPs' focus was specifically on individual depressed patients. Psychiatrists sometimes used a depersonalizing language and designated patients with depressions as "depressions". (Davidsen og Fosgerau 2014: 4)

Citatet er en overvejende tematisk beskrivelse af sprogbrugen, og den er analytisk konsistent med øvrige faggrenes tilgange til at undersøge sundhedsfaglige problemstillinger i repræsentationskontekster, hvor den grammatisk baserede tilgang er underrepræsenteret. De konkrete sproglige strukturer, jeg har påpeget i min analyse, kan dels understøtte Davidsen og Fosgeraus tematisk funderede udsagn, dels give strukturelt belæg for påstande om forståelser af depression. Disse to tilgange kan med fordel kombineres ved først at indkredse passager med en ønsket tematik ved hjælp af IPA-metoden, som dernæst analyseres til bunds ved hjælp af den grammatiske talesprogsanalyse. På denne måde er det ligeledes muligt at højne sammenligneligheden i materialet $i$ en komparativ grammatisk talesprogsanalyse af et givent emne, fx depression. I et bredere perspektiv mener jeg, at de to tilganges potentiale for at berige og supplere hinanden gør det muligt for forskellige fagligheder på tværs af sektorer at mødes i en beskrivelse af det samme genstandsfelt.

Analysen har vist, at der er behov for at skelne mellem en række forskellige realiseringer af gengivet, habituel sprogbrug. Den udgør dermed et væsentligt bidrag både til en videreudvikling af teorien om talegengivelse og til den anvendte forskning i sundhedskommunikation. 
Hanne Sæderup Pedersen

Institut for Nordiske Studier og Sprogvidenskab

Københavns Universitet

sbc846@hum.ku.dk 


\section{LITTERATUR}

Andersen, T.H. \& A. Holsting. 2015. Teksten i grammatikken. Odense: Syddansk Universitetsforlag.

Andersen, T.H. \& F. Smedegaard. 2005. Hvad er meningen? Odense: Syddansk Universitetsforlag.

Armstrong, D., \& G. Earnshaw. 2004. What constructs do GPs use when diagnosing psychological problems? British Journal of General Practice 54(505). 580-583.

Bakhtin, M.M. 1984. Problems of Dostojersky'spoetics. Minneapolis: University of Michigan Press.

Banfield, A. 1982. Unspeakable sentences. Narration and representation in the language of fiction. New York: Routledge.

Chew-Graham, C. A., C.R. May \& S. Headley. 2000. The burden of depression in primary care: A qualitative investigation of general practitioners' constructs of depressed people in the inner city. International Journal of Psychiatry in Clinical Practice 6(4). 137-141. DOI: 10.1185/135525700543352.

Clark, H.H. \& R.J. Gerrig.1990. Quotations as demonstrations. Language 66. 4. 764-805.

Cohn, D. 1978. Transparent minds. Narrative modes for presenting consciousness in fiction. Princeton: Princeton University Press.

Davidsen, A. 2008. Mentalization, narrative and time - a qualitative study about psychological interventions in general practice. København: Månedsskrift for Praktisk Lægegernings Forlag. Ph.d.-afhandling.

Davidsen, A.S. \& C.F. Fosgerau. 2014. What is depression?: Psychiatrists' and GPs' experiences of diagnosis and the diagnostic process. International Journal of Qualitative Studies on Health and Well-Being 9(26866). DOI: 10.3402/qhw.v9.24866.

Davidsen, A. \& S. Reventlow. 2011. Narratives about patients with psychological problems illustrate different professional roles among general practitioners. Journal of Health Psychology 16(6). 959-968. DOI: 10.1177/1359105310397219.

Dowrick, C. 2009. Beyond depression. A new approach to understanding and management. Oxford: Oxford University Press.

Fairclough, N. 1989. Language and power. London: Longman.

Fludernik, M. 1993. The fictions of language and the languages of fiction: The linguistic representation of speech and consciousness. London: Routledge.

Fosgerau, C.F. \& A.S. Davidsen. 2014. Patients' perspectives on antidepressant treatment in consultations with physicians. Qualitative Health Research 24. 641-653. DOI: $10.1177 / 1049732314528813$.

Gask, L. 2005. Overt and covert barriers to the integration of primary and specialist mental health care. Social Science \& Medicine 61(8). 785-794. DOI: 10.1016/j. socscimed.2005.03.038. 
Halliday, M.A. K. \& C.M.I.M. Matthiesssen. 2004. An introduction to functional grammar. London: Routledge.

Hansen, E. \& L. Heltoft. 2011. Grammatik over det danske sprog. København: Det Danske Sprog- og Litteraturselskab.

Heritage, J. \& D.W. Maynard. 2006. Communication in medical care: Interaction between primary care physicians and patients. Cambridge: Cambridge University Press.

Jensen, T.J., \& F. Gregersen. 2016. What do(es) you mean? The pragmatics of generic second person pronouns in modern spoken Danish. Pragmatics 26(3). 417-446. DOI: $10.1075 /$ prag.26.3.04jen.

Leech, G. \& M. Short. 1981. Style in fiction. A linguistic introduction to English fictional prose. London: Longman.

McHale, B. 1978. Free indirect discourse. Poetics and Theory of Literature 3. 249-287.

McIntyre, D. et al. 2004. Investigating the presentation of speech, writing and thought in spoken British English; A corpus-based approach. ICAME Journal (28). 4976.

Nielsen, S.B. 2010. Konversationsanalyse af læge-patient-samtaler: status, overblik og muligheder. NyS, Nydanske Sprogstudier 38. 10-38. DOI: http://dx.doi. org/10.7146/nys.v38i38.13517.

Rathje, M. 2009. Definition af citater i talesprog. NyS, Nydanske Sprogstudier 37. 125155. DOI: http://dx.doi.org/10.7146/nys.v37i37.13508.

Sacks, H., E. Schegloff \& G. Jefferson.1974. A simplest systematics for the organisation of turn-taking for conversation. Language 50(4). 696-735.

Semino, E. \& M. Short. 2004. Corpus stylistics. Speech, writing and thought presentation in a corpus of English writing. London: Routledge.

Short, M. 1988. Speech presentation, the novel and the press. Lancaster Papers in Linguistics 30. 1-26.

Short, M. 1996. Exploring the language of poems, plays and prose. Harlow: Longman.

Smith, J.A., P. Flowers \& M. Larkin 2009. Interpretative phenomenological analysis: Theory, method and research. London: Sage.

Tannen, D. 1989. Talking voices. Repetition, dialogue, and imagery in conversational discourse (Studies in interactional sociolinguistics 6). Cambridge: Cambridge University Press.

Voloshinov, V. 1973. Marxism and the philosophy of language. New York: Seminar Press.

Wodak, R. 1997. Critical discourse analysis and the study of doctor-patient interaction. P. Linell \& B. Nordberg (red.), The construction of professional discourse, 173-200. London: Longman. 